\title{
Critical Study the Application of the Principle of Profit Sharing in Syirkah Mudharabah and Musyarakah in Islamic Banking
}

\author{
Arim Nasim and Elis Mediawati \\ Department of Accounting, Universitas Pendidikan Indonesia
}

\section{Abstract}

The existence of a syari'ah bank in accordance with shari'ah principles has answered some of the problems of the banking system in accordance with the wishes of the Muslims. In practice, there arose suspicion and dissatisfaction from customers of the Syari'ah Bank which had not fully implemented the Shari'ah principles. The application of accounting to Syari'ah banking institutions currently still faces obstacles caused by internal and external factors. This study aims to find out whether the principle of profit

Corresponding Author:

Arim Nasim

arim.nasim@upi.edu

Received: 10 February 2019

Accepted: 14 March 2019

Published: 28 March 2019

Publishing services provided by

Knowledge E

(c) Arim Nasim and Elis

Mediawati. This article is

distributed under the terms of

the Creative Commons

Attribution License, which

permits unrestricted use and

redistribution provided that the

original author and source are

credited.

Selection and Peer-review under the responsibility of the ICIEBP Conference Committee. sharing has been applied in the preparation of financial statements as the basis for profit sharing in syirkah mudharabah and musyarakah. The research methods used in this study are qualitative methods with critical theory. The study was conducted on the application of the profit sharing system applied to financing with the Mudharabah and Musyarakah contract in Islamic financial institutions. The results of the research show that the concept of profit sharing that is applied is revenue sharing, the use of revenue sharing method is based on the existence of the principle of conservatism applied in Islamic financial institutions

Keywords: Syari'ah Bank, profit sharing, Quality of Financial Statements, Musyarakah, Mudharabah.

\section{Introduction}

The establishment of the Syari'ah Bank and the Syariah Financial Institution was an attempt to implement Islamic Shari'a in a gradual and partial manner with the intention of overcoming the weaknesses of this ummah in the field of economy and its welfare.

One of the obstacles from Syariah Banking is the application of Syari'ah Accounting in accordance with the Syari'ah Accounting Standards. The application of accounting to Syariah Banking institutions is still facing obstacles caused by internal and external factors. External factors in the form of syariah accounting theory structure are still in 
the stages of discourse and regulation of information systems, while internal factors include: 1). Lack of human resources who are shari'ah accounting experts, 2). The principle of profit sharing requires honesty from customers and bank managers, 3). The supervision system of the Syariah Supervisory Board is not yet optimal, and 4). Utilization of information technology that has not been optimal. The research results of Suwarno (2005) show that the presentation of Syariah Bank Financial Statements in BPR has not been in accordance with the objectives of the financial statements. The purpose of the Financial Report is, among other things, the compliance of Shariah banks with shariah principles. This is due to internal barriers to Shari'ah banking, including technical expertise that has not been followed by Syariah Accounting conceptual abilities.

\section{Literatur Review}

\subsection{Islamic banking}

There are several definitions of Islamic Banks or Syariah Banks, including: Antonio (1992) defines that Islamic banks are banks that operate in accordance with the principles of Islamic Sharia or Banks whose procedures refer to the provisions of the Qur'an and Hadith.

Whereas Azis (2001) defines Islamic Banks as follows:

Islamic Banks (Banks based on Syari'ah Islam) are banking institutions that use systems and operations based on Syariah Islam. This means that banking operations follow the business procedures based on the Qur'an and Hadith and not the procedures and business agreements that are not guided by alquran and Sunnah Rosululloh Muhammad SAW.

The General Secretary of the OIC (Organitation of the Islamic Conference) defines Islamic Banks as follows:

"An Islamic bank is a financial institution whose status, rules and procedures for expressing its principle of Islamic principles and to the banning of receipts and payments on any of its operations" (Ali \& Sarkar-1995)

From these definitions we can find out that Islamic Banks are a banking system that uses Islamic law as the basis of its operations not only banks that do not use the interest system in their operations but are wider than that. Islamic banks use a variety of mechanisms both in fundraising and in channeling funds such as buying and selling, business cooperation and leasing. One of the important things regarding 
the relationship between banks and the public in Islamic banks is the relationship of partnership not the relationship between the debtor and the creditor. As stated by Bjorklund $(2004,32)$ "The relationship between the Islamic bank and the client is a partnership and not a debtor-creditor.

Ahmad (2004) has explained from the results of his research in various countries about the differences between Islamic Banks and Conventional Banks (see Table 1)

TABLE 1: Differences between Islamic \& Conventional Banking.

\begin{tabular}{|c|c|c|}
\hline Characteristics & Islamic Banking System & $\begin{array}{l}\text { Conventional Banking } \\
\text { System }\end{array}$ \\
\hline Guiding principle & $\begin{array}{l}\text { Guided by Quranic edicts, } \\
\text { Hadeeth, Islamic ethics } \\
\text { and Islamic laws. }\end{array}$ & $\begin{array}{l}\text { Guided by profit motive } \\
\text { alone, with no religious or } \\
\text { ethical considerations. }\end{array}$ \\
\hline Ethics of financing & $\begin{array}{l}\text { Financing being } \\
\text { asset-backed, and meant } \\
\text { for productive use helps } \\
\text { reduce the overall debt } \\
\text { burden. }\end{array}$ & $\begin{array}{l}\text { Debt burden arising out of } \\
\text { excessive use of credit } \\
\text { leads to bankruptcies, and } \\
\text { waste of financial } \\
\text { resources. }\end{array}$ \\
\hline Liquidation Assets & $\begin{array}{l}\text { An Investment Account } \\
\text { Holder will have similar } \\
\text { rights as shareholders. }\end{array}$ & $\begin{array}{l}\text { Depositors are paid before } \\
\text { the shareholders. }\end{array}$ \\
\hline $\begin{array}{l}\text { Involvement of risk \& } \\
\text { Equity financing }\end{array}$ & $\begin{array}{l}\text { Equity financing is } \\
\text { available to a project or } \\
\text { venture that involves } \\
\text { profit-and-loss sharing. } \\
\text { Risk-sharing and profit } \\
\text { sharing go together. }\end{array}$ & $\begin{array}{l}\text { Commercial banks do not } \\
\text { usually indulge in equity } \\
\text { financing, only venture } \\
\text { capital companies and } \\
\text { investment banks do. } \\
\text { Conventional banks carry } \\
\text { much less risk, major part } \\
\text { of the risks being } \\
\text { transferred to the } \\
\text { borrowers. }\end{array}$ \\
\hline
\end{tabular}

According to Chapra (1988) Islamic banks are not only interest-free banking institutions but also an institution that can improve the distribution of income and wealth and increase equity participation in the economy.

\subsection{Islamic bank financing products}

The types of financing transactions from Islamic banking according to are:

1. Mudharabah, namely business cooperation between Shahibul Maal (capital owner) and Mudarib (fund manager) with a profit sharing ratio according to the agreement in advance.

2. Musyarakah It is a contract of cooperation that occurs between Capital owners (musyarakah partners) to combine capital and conduct business together in a 
TABLE 2: Lanjutan.

\begin{tabular}{|c|c|c|}
\hline Return on Capital & $\begin{array}{l}\text { Depends on productivity, } \\
\text { idle money cannot earn } \\
\text { any return. Money is not } \\
\text { capital per se, only } \\
\text { potential capital. }\end{array}$ & $\begin{array}{l}\text { Even idle money in bank } \\
\text { deposits earns returns. }\end{array}$ \\
\hline $\begin{array}{l}\text { Prohibition of Gharar } \\
\text { (uncertainty) }\end{array}$ & $\begin{array}{l}\text { The existence of } \\
\text { uncertainty in a contract is } \\
\text { prohibited because it } \\
\text { requires the occurrence of } \\
\text { an event which may not } \\
\text { ultimately occur. "Full } \\
\text { disclosure" by both parties } \\
\text { is the norm in contracts. } \\
\text { Derivatives trading e.g. } \\
\text { options are considered as } \\
\text { having elements of Gharar. }\end{array}$ & $\begin{array}{l}\text { Trading and dealing in } \\
\text { derivatives are widely } \\
\text { considered as the main } \\
\text { source of liquidity in the } \\
\text { conventional financial, } \\
\text { commodity and capital } \\
\text { markets. }\end{array}$ \\
\hline Profit and Loss Sharing & $\begin{array}{l}\text { Most transactions are } \\
\text { based on this variable } \\
\text { returns, dependent on } \\
\text { lenders' performance. } \\
\text { Greater share of risks } \\
\text { forces them to manage } \\
\text { risks more professionally, } \\
\text { to ensure better returns } \\
\text { than conventional } \\
\text { accounts. Depositors \& } \\
\text { investors have opportunity } \\
\text { to earn higher returns than } \\
\text { in conventional systems. }\end{array}$ & $\begin{array}{l}\text { There is no relationship } \\
\text { between bank } \\
\text { performance and returns } \\
\text { to the depositors or } \\
\text { investors, who mostly } \\
\text { enjoy a risk-free return. } \\
\text { Conventional institutions } \\
\text { mostly act as } \\
\text { intermediaries between } \\
\text { lenders \& borrowers } \\
\text { enjoying almost a risk-free } \\
\text { spread. }\end{array}$ \\
\hline Zakat & $\begin{array}{l}\text { It has become one of the } \\
\text { functions of the Islamic } \\
\text { banks to collect and } \\
\text { distribute Zakat. }\end{array}$ & $\begin{array}{l}\text { Government Taxes } \\
\text { perhaps serve the same } \\
\text { purpose - mode and rate } \\
\text { of charging are different, } \\
\text { though. }\end{array}$ \\
\hline
\end{tabular}

partnership, with the profit sharing ratio in accordance with the agreement, while the loss is borne proportionally according to the capital contribution.

3. Murabahah is a contract of sale and purchase of goods by stating the acquisition price and profit agreed upon by the seller (Bank) and Buyer (customer).

4. Salam is a contract of sale and purchase muslam fiih (ordered goods) with suspension of delivery by muslam ilaihi (seller) and repayment is done immediately by the buyer before the ordered goods are received with certain conditions. In this Salam the Bank can act as a buyer or seller. If the bank acts as a seller then orders the other party to supply ordered goods by way of greetings, this is called parallel greetings. 
5. Isthisna is a buyer (mashnu ') buying contract (mustashni') with the recipient of the order (shani) who also acts as a seller. Even though specifications (type, type, size, quality, quantity) and price of ordered goods are agreed at the beginning of the contract with payments made in accordance with the agreement (upfront, installments and backward) and if the bank acts as shani 'then appoints another party to make goods called parallel istishna.

6. ljarah is the contract of transfer of usufructuary rights over goods or services, through payment of rent without being followed by transfer of ownership of goods. If it ends with the surrender of ownership called ljarah Waiqtina or ljarah Muntahia Bitamlik.

\section{Research Methods}

This research uses qualitative methods. According to Anis (2011), qualitative research is research carried out in certain settings that exist in real life (natural) with the intention of investigating and understanding phenomena: what happens, why it occurs and how it occurs? Whereas the research approach used is critical theory According to Neuman in Turiman (2011), critical approaches are more aimed at fighting for the ideas of researchers to bring substantial changes to society. Research is no longer producing neutral / impartial and apolitical scientific papers, but rather is a tool to change social institutions, ways of thinking, and people's behavior in a direction that is believed to be better. Therefore, in this approach a deep understanding of a phenomenon based on the facts of the field needs to be supplemented by analysis and opinions based on the personal circumstances of the researcher, provided that adequate arguments are supported

\section{Results and Discussion}

\subsection{The concept of profit sharing on Syirkah Mudharabah and Musyarakah in islamic financial institutions}

Syirkah is a contract of cooperation between two or more parties, which agrees to conduct a joint business with the aim of gaining profit or profit. Cooperation or Syirkah involving assets or capital with two types of staff or managers, namely Syirkah Mudharabah and Syirkah Inan or Musyarakah. Syirkah mudhârabah is syirkah between two parties provided that one party contributes work ('charity), while the other party 
contributes property capital (mâl) while Syirkah inân is a collaboration between two or more parties who each contribute work (' charity) and property capital (mâl).

The distribution of syirkah benefits both syirkah mudharbah or syirkah musyarakah must be based on mutual agreement. They can share it equally (fifty-fifty) and may not be the same. This provision is based on the Hadith Rasululloh SAW from Ali ra. said:

$$
\text { الربح على ما اصطلحوا عليه }
$$

Profits are based on their agreement (parties who share) (HR Abdurrazzak, in al-Jami')

So the size of the profit ratio that is part of each syarik, both managers and investors, must be agreed upon. The amount of the profit ratio can be agreed by taking into account the share of each contribution both labor and capital; it can also without regard to it. The amount of profit may not be determined by its nominal value, but only in the form of a ratio or percentage of profit.

While losses are borne by each business partner (sharîk) based on the portion of capital in accordance with the hadith below.

$$
\text { الوضيعة على المال و الربح على ما اصطلحوا عليه }
$$

"Losses are based on the amount of capital" (HR. Abdurrazzak)

While losses are borne by each business partner (sharîk) based on the portion of capital. If each capital is $50 \%$, then each of them bears a loss of $50 \%$. The syirkah inan parties may not require losses based on agreement, but must be in accordance with the amount of assets they make as capital in this syirkah.

Based on these provisions, in the Accounting concept, the intended profit is defined as profit after deducting cost of goods sold and operational costs.

\subsection{Practice of profit sharing in Syirkah Mudharabah and Musyarakah in islamic financial institutions}

Based on the fatwa of the National Sharia Council (DSN) No: 15 / DSN-MUI / IX / 2000 Concerning Principles of Distribution of Business Results in Islamic Financial Institutions, Islamic Financial Institutions are given the freedom to choose an approach that divides the results of operations among parties the form of cooperation may be based on the principle:

1. Profit Sharing, which is profit sharing calculated from income after deducting capital (ra'su al-mal) and costs.

2. Net Revenue Sharing, namely profit sharing calculated from income after deducting capital (ra'su al-mal). 
According to the DSN fatwa 2 , the methods each have advantages and disadvantages, to see the differences between the two methods and the impact on each company's income can be seen in the example in Table 3 below:

TABLE 3: Perbandinga Revenue Sharing dan Propit Sharing (in 000.000).

\begin{tabular}{l|c|c|}
\hline Descriptions & Ammount & \multicolumn{1}{c|}{ Metode } \\
\hline Sales & $\mathbf{1 0 0}$ & Revenue Sharing \\
\hline Cost Of Good Sold & 65 & \\
\hline Gross Profit & 35 & \\
\hline Expense: & 25 & \\
\hline Net Profit & $\mathbf{1 0}$ & Profit Sharing \\
\hline Source: Hasil Pengolahan Data & & \\
\hline
\end{tabular}

Refunds on the basis of the Musharaka contract are carried out in two ways, namely in installments or at the end of the period, in accordance with the financing period. Each time the customer returns the capital to the bank, the level of ownership of the business assets will increase. Conversely, bank ownership of business assets will decrease. If the customer repays all the capital supplied by the bank, the business asset is fully owned by the customer.

The results of research in Islamic financial institutions at point 4.2 show that the practice of profit sharing is not right and optimal in accordance with sharia principles because most of the profit sharing used uses the revenue sharing method. The use of revenue sharing method is based on the existence of the principle of conservatism applied in the accounting of Islamic financial institutions. Yet according to Muhammad Akhyar the principle of conservats, Historical Cost and materiality are conventional accounting principles that are contrary to Islam.

The results of this study are in accordance with the Teory of Economic of Islam, according to Abdul Hamid Abu Sulaiman in Chapra (Chapra,2000); Only replacing interest-based loans with other forms of interest or only profit sharing fails to offer a real alternative. Therefore, Yaya (2001) argues that an extensive overhaul of conventional accounting is needed to become shariah accounting. He holds that conventional accounting failed to achieve socio-economic goals in Islam. The socio-economic goals in Islam are the foundation in every Islamic jurisprudence / rule relating to economic issues because the current economic problems are very complicated while some of them are not regulated directly by the principles of shari'ah. 


\section{Conclusions, Implications and Limitations}

\subsection{Conclusions}

Based on the problem formulation and analysis of research results, the conclusions in this study can be described as:

1. Distribution of syirkah profits must be based on mutual agreement while borne by investors or in accordance with the portion of capital each. This provision is based on the Hadith Rasululloh SAW from Ali ra. said: Profits are based on their agreement (parties who share) (HR Abdurrazzak, in al-Jami '). Whereas the loss is borne by each business partner (syarîk) based on the portion of capital in accordance with the hadith of Rasululloh SAW:. Losses are based on the amount of capital "(HR. Abdurrazzak)

2. Based on the DSN Fatwa, Islamic Financial Institutions are given the freedom to choose the Profit Sharing approach, namely profit sharing calculated from aftercapital income (ra'su al-mal) and costs and the Profit Sharing Principle (Net Revenue Sharing), namely profit sharing calculated from income after deducting capital (ra'su al-mal).

3. The practice of profit sharing has not been right and optimal in accordance with sharia principles because most of the profit sharing used uses the revenue sharing method. The use of revenue sharing method is based on the principle of conservatism and this still contradicts Islamic Shari'a because profit divided is not actual profit

\subsection{Implications and limitations of research}

This research can contribute to the development of a study of the application of sharia accounting within Islamic Financial Institutions appropriately so as to produce economic actors who cling to the application of Islamic principles and sharia to an economic transaction so that justice is realized. This study has a variety of limitations including the number of respondents who are still few and very simple research methods.

[1] Antonio, Muhammad Syafi'i (1999), Bank Syariah Wacana Ulama dan Cendikiawan. Bogor: Tazkia Institute 
[2] Anis Chairi (2011), Materi Workshop Metode Penelitian Kualitatif, Di sampaikan dalam acara Diskusi Ilmiah, Program Studi Akuntansi-Universitas Pendidikan Indonesia.

[3] Ali, M and Sarkar, A. A. (1995). "Islamic Banking: Principles and Operational Methodology". Thoughts on Economics, Vol. 5 No. 3 \& 4. July-December 1995. Dhaka: Islamic Economics Research Bureau.

[4] Ahmad, S., 2004, Islamic Banking and Finance in The Contemporary World, DISSERTATION, diakses melalui: http://www.xlri-dubai.net/

[5] M.Amin Aziz, 1992, Mengembangkan Bank Islam di Indonesia, Bankir, Jakarta.

[6] Björklund,Irene. 2004. Islamic Banking: An Alternative System, Dissertation, Kristianstad University College diakses melalui: http://www.islamic-banking.com

[7] Antonio, Muhammad Syafi'i. 2001. Bank Syariah: Dari Teori ke Praktik. Jakarta: Gema Insani Press.

[8] Suwarno, 2005. Analisis Hambatan Dalam Penerapan Akuntansi Syariah pada Bank Syariah: Studi Kasus pada Bank Amal Sejahtera dan Bank Syariah Mandiri, Tesis. Universitas Airlangga.

[9] Sarker, A.A. 1999. Islamic Bussiness Contract, Agency Problem and Theory Of Islamic Firm, International Journal Of Islamic Financial Service. Vol. 1 No. 2 July-September [10] Umer Chapra, Sistem Moneter Islam, Jakarta, Gema Insani, 2000

[11] Yaya, Rizal. 2001. From Conventional Accounting to Is/amic Acconting, Does it need A slight or Extensive Overhaul? Jurnal Akuntansi dan Auditing Indonesia Vol.5 No 2 Desember 2001 